\title{
The Age of Responsibility: CSR 2.0 and the New DNA of Business
}

\author{
Wayne Visser \\ University of Birmingham, United Kingdom
}

\begin{abstract}
This paper argues that CSR, as a business, governance and ethics system, has failed. This assumes that success or failure is measured in terms of the net impact (positive or negative) of business on society and the environment. The paper contends that a different kind of CSR is needed if we are to reverse the current direction of many of the world's most pressing social, environmental and ethical trends. The first part of the paper reviews business's historical progress over the Ages and Stages of CSR: moving through the Ages of Greed, Philanthropy, Marketing and Management, using defensive, charitable, promotional and strategic CSR approaches respectively. The second part of the paper examines the Three Curses of Modern CSR (incremental, peripheral and uneconomic), before exploring what CSR might look like in an emerging Age of Responsibility. This new CSR - called systemic or radical CSR, or CSR 2.0 - is based on five principles (creativity, scalability, responsiveness, glocality and circularity) and forms the basis for a new DNA model of responsible business, built around the four elements of value creation, good governance, societal contribution and environmental integrity.
\end{abstract}

\section{Keywords}

Corporate sustainability and responsibility, business, governance, ethics

It is easy to dodge our responsibilities, but we cannot dodge the consequences of dodging our responsibilities.

- Josiah Charles Stamp

\section{Taking Stock on CSR}

My starting point for any discussion on CSR - by which I mean corporate sustainability and responsibility, but choose whichever label you prefer (corporate social responsibility, corporate citizenship, sustainability, business ethics) - my starting point is to admit that CSR has failed. The logic is simple and compelling. A doctor judges his/her success by whether the patient is getting better

Copyright (C) 2010 Victoria University. This document has been published as part of the Journal of Business Systems, Governance and Ethics in both online and print formats. Educational and non-profit institutions are granted a nonexclusive licence to utilise this document in whole or in part for personal or classroom use without fee, provided that correct attribution and citation are made and this copyright statement is reproduced. Any other usage is prohibited without the express permission of the publisher. (healthier) or worse (sicker). Similarly, we should judge the success of CSR by whether our communities and ecosystems are getting better or worse. And while at the micro level - in terms of specific CSR projects and practices - we can show many improvements, at the macro level almost every indicator of our social, environmental and ethical health is in decline.

1 Based on the author's forthcoming book of the same title (Visser, 2011). 
I am not alone in my assessment or conclusion. Paul Hawken stated in The Ecology of Commerce (1994) that 'if every company on the planet were to adopt the best environmental practice of the "leading" companies, the world would still be moving toward sure degradation and collapse.' Unfortunately, this is still true. Jeffrey Hollender, founder and CEO of Seventh Generation, agrees, saying: 'I believe that the vast majority of companies fail to be "good" corporate citizens, Seventh Generation included. Most sustainability and corporate responsibility programs are about being less bad rather than good. They are about selective and compartmentalized "programs" rather than holistic and systemic change' (Hollender \& Breen, 2010).

In fact, there are no shortage of critics of CSR. Christian Aid (2004) issued a report called 'Behind the Mask: The Real Face of CSR', in which they argued that 'CSR is a completely inadequate response to the sometimes devastating impact that multinational companies can have in an ever-more globalised world - and it is actually used to mask that impact.' A more recent example is an article in the Wall Street Journal called 'The Case Against Corporate Social Responsibility', which claims that 'the idea that companies have a responsibility to act in the public interest and will profit from doing so is fundamentally flawed' (Karnani, 2010). This is not the place to deconstruct these polemics. Suffice to say that they raise some of the same concerns I have and which I discuss in this paper.

There are a number of ways to respond to my assertion that CSR has failed. One is to disagree with the facts and to suggest that things are getting better, not worse, as do the likes of Bjørn Lomborg in his Skeptical Environmentalist (2001). I find the overwhelming evidence to the contrary, which is widely available from credible sources like the United Nations and Transparency International, both compelling and convincing ${ }^{2}$. Second, you might argue that solving these complex social, environmental and ethical problems is not the mandate of CSR, nor within its capacity to achieve. Certainly, business certainly cannot tackle our global challenges alone, but unless CSR is actually about solving the problems and reversing the negative trends, what is the point?

\section{The Ages and Stages of CSR}

The impotence of CSR in the face of more systemic problems has been nowhere more evident than in the global financial crisis. I have argued elsewhere that the global financial crisis represents 'a multilevel failure of responsibility - from the individual and corporate level to the finance sector and entire capitalist system' (Visser, 2010). Underlying this failure of responsibility lies a cancer of greed that has corrupted our business systems, governance and ethics, particularly in our Western economies.

However, it would be unfair and inaccurate to characterise all business activity as motivated by greed. Rather, it is my contention that the evolution of business responsibility can be best understood in terms of five overlapping ages - the Ages of Greed, Philanthropy, Marketing, Management and Responsibility. I believe that each of these ages typically manifests a different stage of CSR, namely Defensive, Charitable, Promotional, Strategic and Systemic CSR respectively. Furthermore, companies tend to move through these ages and stages, although they may have activities in several modes at once. Table 1 briefly outlines each Age. Furthermore, they can be described as follows.

Table 1: The Ages and Stages of CSR

\begin{tabular}{|l|l|l|l|l|}
\hline Economic Age & Stage of CSR & Modus Operandi & Key Enabler & Stakeholder Target \\
\hline Greed & Defensive & Ad hoc interventions & Investments & $\begin{array}{l}\text { Shareholders, government \& } \\
\text { employees }\end{array}$ \\
\hline Philanthropy & Charitable & $\begin{array}{l}\text { Charitable } \\
\text { programmes }\end{array}$ & Projects & Communities \\
\hline Marketing & Promotional & Public relations & Media & General public \\
\hline Management & Strategic & Management systems & Codes & Shareholders \& NGOs/CSOs \\
\hline Responsibility & Systemic & Business models & Products & Regulators \& customers \\
\hline
\end{tabular}

2 Consider, for example, the UN Millennium Ecosystem Assessment the TI Corruption Perceptions Index 
The Age of Greed is characterised by Defensive CSR in which all corporate sustainability and responsibility practices - which are typically limited are undertaken only if and when it can be shown that shareholder value will be protected as a result. Hence, employee volunteer programmes (which show evidence of improved staff motivation, commitment and productivity) are not uncommon, nor are expenditures (for example in pollution controls) which are seen to fend off regulation or avoid fines and penalties.

Charitable CSR in the Age of Philanthropy is where a company supports various social and environmental causes through donations and sponsorships, typically administered through a Foundation, Trust or Chairman's Fund and aimed at empowering community groups or civil society organisations.

Promotional CSR in the Age of Marketing is what happens when corporate sustainability and responsibility is seen mainly as a public relations opportunity to enhance the brand, image and reputation of the company. Promotional CSR may draw on the practices of Charitable and Strategic CSR and turn them into PR spin, which is often characterised as 'greenwash'.

Strategic CSR, emerging from the Age of Management, means relating CSR activities to the company's core business (e.g. Coca-Cola and water management), often through adherence to CSR codes and implementation of social and environmental management systems, which typically involve cycles of CSR policy development, goal and target setting, programme implementation, auditing and reporting.

Finally, Systemic CSR in the Age of Responsibility focuses its activities on identifying and tackling the root causes of our present unsustainability and irresponsibility, typically through innovating business models, revolutionising their processes, products and services and lobbying for progressive national and international policies.

Hence, while Strategic CSR is focused at the micro level - supporting social or environmental issues that happen to align with a company's strategy, but without necessarily changing that strategy Systemic CSR focuses on understanding the interconnections in the macro level system (society, communities, economies and ecosystems) and changing a company's strategy to optimise the outcomes for this larger human and ecological system.

Ideally, therefore, businesses should make the journey to Systemic CSR in the emerging Age of Responsibility, building on each previous stage of maturity. If on the other hand companies remain stuck in any of the first four stages, our ability to turn the tide on the environmental, social and ethical crises that we face will be seriously compromised. Simply put, CSR will continue to fail.

\section{Curses of Modern CSR}

But why is CSR failing in the first four modes? I believe this can be explained the three 'curses', or fundamental failings, of modern CSR.

Table 2: The Curses of Modern CSR

\begin{tabular}{|l|l|}
\hline Curses & Nature of the Failing \\
\hline $\begin{array}{l}\text { Peripheral } \\
\text { CSR }\end{array}$ & $\begin{array}{l}\text { CSR has remained largely restricted to the largest companies, and mostly confined to } \\
\text { PR, or other departments, rather than being integrated across the business }\end{array}$ \\
\hline $\begin{array}{l}\text { Incremental } \\
\text { CSR }\end{array}$ & $\begin{array}{l}\text { CSR has adopted the quality management model, which results in incremental } \\
\text { improvements that do not match the scale and urgency of the problems }\end{array}$ \\
\hline $\begin{array}{l}\text { Uneconomic } \\
\text { CSR }\end{array}$ & $\begin{array}{l}\text { CSR does not always make economic sense, as the short-term markets still reward } \\
\text { companies that externalise their costs to society }\end{array}$ \\
\hline
\end{tabular}

\section{Peripheral CSR}

The first of these curses is the Curse of Peripheral CSR. Using BP as an example, here is a company with a long and mostly proud history, contributing highly useful products to society and practicing CSR management. Leaving the safety and environmental disasters aside for a moment, BP has made 
serious commitments to sustainability and responsibility and achieved a great deal in terms of measurable improvements in its safety, health, environmental, labour and human rights performance. And yet for all their flagship leadership in the Age of Management, we see that CSR has remained on the periphery. BP has not gone 'beyond petroleum'; quite the opposite in fact.

It is the same for almost all companies practicing CSR. At worst - and I see this especially in developing countries that are stuck in the Philanthropic or Promotional CSR mode - CSR sits in a public relations, marketing, corporate affairs or human resources department. It is an 'add-on', explicitly used to improve brand equity or the company's reputation. At best - and more common in developed countries and among subsidiaries of multinationals - we see companies practicing Strategic CSR, trying to align CSR activities with their industry impacts, or embedding CSR through management systems. Even so, they completely fail to change the strategic direction or core business of the company, or the harmful effects of its processes, products and services.

What BP and Enron and virtually every other leader in the Ages of Marketing and Management have in common is not the deliberate intention to mislead (although there are clear examples of this too), but rather a corporate culture - supported by a system of narrow institutional performance incentives, short-term market pressures and perverse economic measures of progress - that remains essentially in conflict with the objectives of sustainability and responsibility. When a trade-off has to be made between financial profitability and ethical standards, the choice is clear, irrespective of carefully crafted codes of practice on the boardroom wall. If there is a tug-of-war between economic growth and environmental impacts, the winner is clear, despite any number of ISO 14001 certificates. If customer demand for cheap products is at odds with fair labour conditions, consumerism triumphs over the needs of powerless workers in the supply chain from some far-flung land.

Once again, examples are not hard to find. In July 2010, Marlboro cigarette manufacturer Philip Morris International acknowledged 'serious concerns' after Human Rights Watch found 72 cases of child labour in a remote region of Kazakhstan - with children as young as 10 in dismal conditions picking tobacco destined for the global company. Similarly, the UK retailer Poundland was recently exposed for sweatshop activities, when a boy of seven was found to be working 100 hours a week in an Indian factory, earning just $7 \mathrm{p}$ an hour to make napkin rings for the cut-price chain.

CSR has remained peripheral in another way. It hardly ever extends beyond the large, high-visibility branded companies in any country. All the CSR indexes and rankings, the CSR codes and standards, the CSR reports and audits are focused on a few thousand companies. The Global Reporting Initiative celebrated 1,000 reports in 2008 that are using their guidelines. SA 8000 certification still only covers 2,000 'facilities'. The UN Global Compact has 5,300 participants. These numbers are peripheral by any measure you care to choose. Even ISO 14001, with almost 190,000 certifications worldwide, pales into insignificance when you consider that the U.S. Chamber of Commerce alone has more than 3 million members. If we are honest, CSR is the preserve of a tiny corporate elite, a miniscule business minority.

\section{Incremental CSR}

Closely linked with the Peripheral curse - and driven by the Age of Management - is the Curse of Incremental CSR. To fully appreciate this issue, we have to go back to business guru Peter Drucker's 1954 book The Practice of Management (Drucker, 1993), in which he introduced the concept of 'management by objectives', or MBOs. The concept is so endemic now as to seem like common sense, but it was quite a revolutionary concept at the time. The basic idea is to translate corporate strategy into a series of measurable objectives, which can be cascaded down through the organisation. This allows managers to track and incentivise performance, while employees know what is expected of them and can reap the rewards if they meet their targets. Furthermore, if they participate in setting those objectives, they are likely to feel more motivated and empowered.

The MBO approach - together with subsequent tools like the Balanced Scorecard - is right at the heart of the Age of Marketing, in the sense that draws attention to voluntary incremental improvements, which distracts attention from the larger problems and deeper impacts of the business. In one of those bizarre ironies of history, the 'system' that would do more to embed the MBO approach than anything 
else was conceived by one of MBO's great detractors. I am referring to W. Edwards Deming and his total quality management (TQM) approach. Deming credits the inspiration for his theory of management to a 1927 meeting with Walter A. Shewhart of the Bell Telephone Laboratories, the originator of the concepts of statistical control of processes. Years later, during Allied occupation of Japan, Deming was asked by the U.S. military to assist with the 1951 Japanese Census.

This led to an invitation by the Japanese Union of Scientists and Engineers (JUSE) for Deming to teach statistical control and quality management to its members. Japan's CEOs were impressed with Deming's idea that improving quality would reduce expenses, while increasing productivity and market share, and began to test and implement TQM in their factories, notably in their nascent motor industry. Not only did this assist Japan's economic rise in the second half of the $20^{\text {th }}$ century, but it also spawned the international quality movement.

The TQM approach was later standardized through ISO 9001, first launched in 1987. By the end of 2008, nearly a million certifications had been issued. The key to total quality management, according to ISO 9001, is continuous improvement, which is predicated on setting objectives and reviewing performance against them. The designers of the standard seem to have overlooked (or ignored) Deming's objection to MBOs. Deming argued that a lack of understanding of systems commonly results in the misapplication of objectives. By contrast, a leader with an understanding of systems was more likely to guide workers to an appropriate solution than the incentive of an objective.

This debate is important for the responsibility debate because the most widely practiced CSR standard, ISO 14001, is explicitly designed to apply the ISO 9001 approach to management systems, including MBOs, to environmental management. That is not a bad thing in and of itself, and it has resulted in many welcome incremental improvements in the environmental performance of companies processes. But the Achilles heel of ISO 14001 and all the other voluntary CSR standards that use MBOs is this: companies set their own objectives and make progress at their own pace and discretion. Furthermore, as with the Peripheral Curse, the MBOs approach has failed to challenge or significantly change companies largest negative impacts, which that are associated with either the nature of their business, the consumption-driven lifestyle they promote, or the impacts of their resource- and energy-intensive products and services.

The net effect is that, despite more CSR than ever before, and despite laudable incremental improvements in CSR performance at the micro level, virtually every macro-level indicator we have of social, environmental or ethical quality - be it the gap between rich and poor, deforestation, biodiversity loss, or corruption - shows that things are still getting worse, not better. The incremental approach to CSR simply does not produce the scale and urgency of response that is required, nor does it get to the root of business's systemic unsustainability and irresponsibility in the shareholder-driven, growth-obsessed capitalist global economy.

\section{Uneconomic CSR}

The third and final curse of modern CSR is that the much touted 'business case' for CSR is not nearly as obvious, certain or practiced as many assume. Let's start with the rhetoric. The World Business Council for Sustainable Development (WBCSD), which is the strongest proponent of the business case, suggests that it is predicated on five 'returns': operational efficiency, risk reduction, recruitment and retention of talent, protecting the resource base of raw materials, and creation of new markets, products and services. And it is certainly not hard to find ad-hoc examples of each of these 'win-wins'. But is there always a business case?

To answer this, we must look beyond the rhetoric and turn to academic research. The findings vary. For example, Griffin and Mahon (1997) reviewed 25 years of studies and found that a majority showed a positive link between CSR and financial performance, while Margolis and Walsh (2001) reviewed 80 studies, of which 42 show a positive relationship, 19 demonstrate no relationship and four find a negative one. Two reports by SustainAbility - Buried Treasure (2001) and Developing Value (2002) - also suggest mixed results. Some relationships between sustainability factors and business success factors are stronger than others, and in many cases, no relationship exists. Economist Arthur Laffer, on the other hand, in a review of Business Ethics magazine's 100 Best Corporate Citizens 
found 'no significant positive correlation between CSR and business profitability as determined by standard measures' (Gupte, 2005).

Academic and author of The Market for Virtue, David Vogel (2005), concluded that 'there is no definitive answer to the question of a financial link. It depends on an individual company's circumstances. Academics searching for a definitive corporate responsibility-financial performance link are barking up the wrong tree.' I tend to agree. There are far too many variables to isolate the impact of CSR on financial performance, except through very specific examples like eco-efficiency. What's more, are typical measures of CSR a reliable proxy for sustainability and responsibility? After all, if we had correlated Enron's CSR and financial performance prior to its demise, it would have pointed to a strong positive relationship, which makes a nonsense of the whole exercise.

I have a more fundamental problem with the misdirection of CSR business case rhetoric however. The real question we should be asking is: Does the market consistently reward sustainable and responsible performance by companies? Even without checking the data, we know intuitively from what we see going on in the world that the answer is an unequivocal no. With very few exceptions, the global markets today reward the externalisation of social, environmental and ethical costs over the short term. New York Times journalist and author Thomas Friedman (2008) calls this the privatization of benefits and the socialisation of costs, while activist writers like Naomi Klein (2000) call it 'the race to the bottom', referring to tendency for companies to locate their production in places with the lowest labour or environmental standards, and hence the lowest costs.

To underscore the point, the Vice Fund (VICEX) in the U.S., which only invests in the so-called 'sin' industries like tobacco, alcohol, gambling and armaments consistently outperforms the market over the long term, including socially responsible funds like the Domini Social Equity Mutual Fund (DSEFX). However, we don't need to go to extremes to prove the uneconomic nature of responsibility. Why are fairtrade and organic products, or renewable energy, more expensive than more generic products? Why does Exxon remain one of the largest and most profitable companies in the world? The fact of the matter is that, beyond basic legal compliance, the markets are designed to serve the financial and economic interests of the powerful, not the idealistic dreams of CSR advocates or the angry demands of civil society activists.

What's more, business leaders agree. The 2010 survey of 766 CEOs by the UN Global Compact and Accenture found that $34 \%$ cited lack of recognition from the financial markets as a barrier to achieving their sustainability goals.

\section{The Age of Responsibility}

These three curses are why CSR has failed in the Ages of Greed, Philanthropy, Marketing and Management. What makes the Age of Responsibility - and showcase leaders like Ray Anderson and Interface - different from, say, BP (Age of Marketing) or Cadbury's (Age of Management), is the depth of their admission and the scale of their ambition. Anderson's latest book is called Confessions of a Radical Industrialist (2009), in which he concedes not only that today's economic system is broken, but that he and his company are part of the problem. He is able to see himself as a plunderer not through malicious intent, or even greed, but by failing to question the true impacts of business on society and the environment. As Alcoholics Anonymous will tell you, admission is the first step to recovery. Unfortunately, most companies stuck in the Ages of Greed, Philanthropy, Marketing and Management are all still in denial, thinking that either there is no problem, or it's not their problem, or that it's a problem to benefit from, or that it's only a minor problem.

The Age of Responsibility is not just about admission though; it's also about ambition. As far as I can tell, Interface was the first major company to set the BHAG (big hairy audacious goal) of zero negative impact, as well as going beyond 'no harm' to also become a restorative business - to genuinely make things better and leave this world with a net-positive balance. It is only such audacious goals that can lift the triple curses of incremental, peripheral and uneconomic CSR. As Robert Francis Kennedy reminds us: 'There are those who look at things the way they are, and ask why. I dream of things that never were, and ask why not?' We need more pragamatic 
dreamers, business leaders who practice what brain-mind researcher and author Marilyn Ferguson calls 'pragmagic'.

Anderson was not the first radical business leader, nor perhaps even the most radical. The late Anita Roddick, founder of the Body Shop International, had a missionary zeal that few will ever rival. Famous for her business-led activism, which began as an alliance with WWF in 1986 to save the whale, she went on to tackle issues as far ranging as animal rights, women's self-esteem, human rights, fair trade and indigenous people's rights. In her autobiography, Business As Unusual (2001), she distilled her philosophy as follows: 'Business is a renaissance concept, where the human spirit comes into play. It does not have to be drudgery; it does not have to be the science of making money. It can be something that people genuinely feel good about, but only if it remains a human enterprise.'

Ben Cohen and Jerry Greenfield who 'hated running but loved food' and therefore founded Ben \& Jerry's ice cream, became flag bearers for a more radical kind of responsibility as well. Their mission 'to make the best possible ice cream in the nicest possible way' was not just sweet talk. They put it into action in various ways, from going free range and supporting fairtrade to setting up a Climate Change College and sponsoring research into eco-friendly refrigeration. Their biography, The Inside Scoop: How Two Real Guys Built a Business with a Social Conscience and a Sense of Humor (1994), tells the story. 'If you open up the mind,' they concluded, 'the opportunity to address both profits and social conditions are limitless. It's a process of innovation.'

Ricardo Semler (1989, 1993), CEO of the Brazilian manufacturing company Semco, is another selfconfessed maverick who turned many assumptions about 'good management' on their head. For example, at Semco he allowed workers to set their own salaries and working hours; he taught everyone in the company, including shop floor workers, how to read a balance sheet; and he made everyone's salary public. 'If you're embarrassed about the size of your salary', he said, 'you're probably not earning it'. His radical philosophy was this: 'Most companies hire adults and then treat them like children. All that Semco does is give people the responsibility and trust that they deserve.'

\section{Web 2.0: Seeds of a Revolution}

Throughout my 20 year career in corporate sustainability and responsibility, these are the kinds of pioneers I have looked to for hope and inspiration. The frustration has been that these 'radical industrialists' have always remained the exception, rather than the rule. They are the outliers, which is fine if - in line with Everett Rogers' Diffusion of Innovation model - they are the innovators that make up $2.5 \%$ of the population. The problem is that most their ideas and practices haven't diffused to the early adopters and the early majority, let alone the late majority and laggards.

So what will it take to get the kind of transformation we need to move beyond innovation towards mass change? I find an analogy is always helpful and in early 2008, I discovered the perfect metaphor: Web 2.0. The term, of course, had been around for a while - coined in 1999 by IT consultant Darcy DiNucci in an article called 'Fragmented Future' and popularised in 2004 by the landmark O'Reilly Media Web 2.0 conference. Tim O'Reilly's 2005 article 'What is Web 2.0' had already become an Early Adopters' touchstone for a rapidly evolving new lexicon, and remains a classic piece. People like me, part of the technosphere's Early Majority, were a bit slower in waking up, and it took Dan Tapscott and Anthony Williams' book Wikinomics (2006) to switch me on to the revolution in progress.

Before coming to why Web 2.0 is a good metaphor for the transformation of CSR, let me try to bed down the concept. Today, Wikipedia defines Web 2.0 as 'web applications that facilitate interactive information sharing, inter-operability, user-centered design and collaboration.' Fair enough, but let's dig a little deeper, drawing on the term's evolution. In 1999, DiNucci was writing for programmers, challenging them to adapt to the increasing use of portable Web-ready devices. This was just a small part of what Web 2.0 would come to mean. In 2005, O'Reilly brainstormed a far more wide ranging list of examples and contrasts between Web 1.0 and Web 2.0. Examples included DoubleClick versus Google AdSense, Britannica Online versus Wikipedia, personal websites versus blogging, publishing versus participation, directories (taxonomy) versus tagging (folksonomy) and 
stickiness versus syndication, to mention but a few. His article concluded with seven core competencies of Web 2.0 companies:

- Services, not packaged software, with cost-effective scalability;

- Control over unique, hard-to-recreate data sources that get richer as more people use them;

- Trusting users as co-developers;

- Harnessing collective intelligence;

- Leveraging the long tail through customer self-service;

- Software above the level of a single device; and

- Lightweight user interfaces, development models and business models.

In 2006, Tapscott and Williams gave an applied view on Web 2.0 in the form of wikinomics, which they defined as 'the effects of extensive collaboration and user-participation on the marketplace and corporate world'. Wikinomics, they said, is based on four principles:

- Openness, which includes not only open standards and content but also financial transparency and an open attitude towards external ideas and resources;

- Peering, which replaces hierarchical models with a more collaborative forum, for which the Linux operating system is a quintessential example;

- Sharing, which is a less proprietary approach to (among other things) products, intellectual property, bandwidth and scientific knowledge; and

- Acting globally, which involves embracing globalisation and ignoring physical and geographical boundaries at both the corporate and individual level.

\section{The Birth of CSR 2.0}

By May 2008, it was clear to me that this evolutionary concept of Web 2.0 held many lessons for CSR. I published my initial thoughts in a short article online entitled CSR 2.0: The New Era of Corporate Sustainability and Responsibility (Visser, 2008), in which I said:

The field of what is variously known as CSR, sustainability, corporate citizenship and business ethics is ushering in a new era in the relationship between business and society. Simply put, we are shifting from the old concept of CSR - the classic notion of 'Corporate Social Responsibility', which I call CSR 1.0 - to a new, integrated conception - CSR 2.0, which can be more accurately labelled 'Corporate Sustainability and Responsibility'. The allusion to Web 1.0 and Web 2.0 is no coincidence. The transformation of the internet through the emergence of social media networks, usergenerated content and open source approaches is a fitting metaphor for the changes business is experiencing as it begins to redefine its role in society. Let's look at some of the similarities.

Table 3: Similarities between Web 1.0 and CSR 1.0

\begin{tabular}{|l|l|}
\hline Web 1.0 & CSR 1.0 \\
\hline $\begin{array}{l}\text { A flat world just beginning to connect itself and } \\
\text { finding a new medium to push out information } \\
\text { and plug advertising. }\end{array}$ & $\begin{array}{l}\text { A vehicle for companies to establish } \\
\text { relationships with communities, channel } \\
\text { philanthropic contributions and manage their } \\
\text { image. }\end{array}$ \\
\hline $\begin{array}{l}\text { Saw the rise to prominence of innovators like } \\
\text { Netscape, but these were quickly out-muscled } \\
\text { Explorer. }\end{array}$ & $\begin{array}{l}\text { Included many start-up pioneers like Traidcraft, } \\
\text { but has ultimately turned into a product for } \\
\text { large multinationals like Wal-Mart. }\end{array}$ \\
\hline $\begin{array}{l}\text { Focused largely on the standardised hardware } \\
\text { and software of the PC as its delivery platform, } \\
\text { rather than multi-level applications. }\end{array}$ & $\begin{array}{l}\text { Travelled down the road of 'one size fits all' } \\
\text { standardisation, through codes, standards and } \\
\text { guidelines to shape its offering. }\end{array}$ \\
\hline
\end{tabular}


Table 4: Similarities between Web 2.0 and CSR 2.0

\begin{tabular}{|l|l|}
\hline Web 2.0 & CSR 2.0 \\
\hline $\begin{array}{l}\text { Being defined by watchwords like 'collective } \\
\text { intelligence', 'collaborative networks' and } \\
\text { 'user participation'. }\end{array}$ & $\begin{array}{l}\text { Being defined by 'global commons', } \\
\text { 'innovative partnerships' and 'stakeholder } \\
\text { involvement'. }\end{array}$ \\
\hline $\begin{array}{l}\text { Tools include social media, knowledge } \\
\text { syndication and beta testing. }\end{array}$ & $\begin{array}{l}\text { Mechanisms include diverse stakeholder } \\
\text { panels, real-time transparent reporting and new- } \\
\text { wave social entrepreneurship. }\end{array}$ \\
\hline $\begin{array}{l}\text { Is as much a state of being as a technical } \\
\text { advance - it is a new philosophy or way of } \\
\text { seeing the world differently. }\end{array}$ & $\begin{array}{l}\text { Is recognising a shift in power from centralised } \\
\text { to decentralised; a change in scale from few } \\
\text { and big to many and small; and a change in } \\
\text { application from single and exclusive to } \\
\text { multiple and shared. }\end{array}$ \\
\hline
\end{tabular}

As our world becomes more connected and global challenges like climate change and poverty loom ever larger, businesses that still practice CSR 1.0 will (like their Web 1.0 counterparts) be rapidly left behind. Highly conscientised and networked stakeholders will expose them and gradually withdraw their social licence to operate. By contrast, companies that embrace the CSR 2.0 era will be those that collaboratively find innovative ways tackle our global challenges and be rewarded in the marketplace as a result.

\section{The Principles of CSR 2.0}

So much for the metaphore of CSR 1.0 and CSR 2.0. However, a metaphor can only take you so far. What was needed was a set of principles against which we could test CSR. These went through a few iterations, but I eventually settled on five, which form a kind of mnemonic for CSR 2.0: Creativity (C), Scalability (S), Responsiveness (R), Glocality (2) and Circularity (0). These principles can be described briefly as follows:

\section{Principle 1: Creativity (C)}

In order to succeed in the CSR revolution, we will need innovation and creativity. We know from Thomas Kuhn's work on The Structure of Scientific Revolutions that step-change only happens when we can re-perceive our world, when we can find a genuinely new paradigm, or pattern of thinking. This process of 'creative destruction' is today a well accepted theory of societal change, first introduced by German sociologist Werner Sombart and elaborated and popularised by Austrian economist Joseph Schumpeter. We cannot, to a paraphrase Einstein, solve today's problems with yesterday's thinking.

Business is naturally creative and innovative. What is different about the Age of Responsibility is that business creativity needs to be directed to solving the world's social and environmental problems. Apple, for example, is highly creative, but their iPhone does little to tackle our most pressing societal needs. By contrast, Vodafone's M-PESA innovation by Safaricom in Kenya, which allows money to be transferred by text, has empowered a nation in which $80 \%$ of the population have no bank account and where more money flows into the country through international remittances than foreign aid. Or consider Freeplay's innovation, using battery-free wind-up technology for torches, radios and laptops in Africa, thereby giving millions of people access to products and services in areas that are off the electricity grid.

All of these are part of the exciting trend towards social enterprise or social business that is sweeping the globe, supported by the likes of American Swiss entrepreneur Stephen Schmidheiny, Ashoka's Bill Drayton, e-Bay's Jeff Skoll, the World Economic Forum's Klaus Schwabb, Grameen Bank's Muhammad Yunus and Volans Venture's John Elkington. It is not a panacea, but for some products and services, directing the creativity of business towards the most pressing needs of society is the most rapid, scalable way to usher in the Age of Responsibility. 


\section{Principle 2: Scalability (S)}

The CSR literature is liberally sprinkled with charming case studies of truly responsible and sustainable projects and a few pioneering companies. The problem is that so few of them ever go to scale. It is almost as if, once the sound-bites and PR-plaudits have been achieved, no further action is required. They become shining pilot projects and best practice examples, tarnished only by the fact that they are endlessly repeated on the CSR conference circuits of the world, without any vision for how they might transform the core business of their progenitors.

The sustainability problems we face, be they climate change or poverty, are at such a massive scale, and are so urgent, that any CSR solutions that cannot match that scale and urgency are red herrings at best and evil diversions at worst. How long have we been tinkering away with ethical consumerism (organic, fairtrade and the like), with hardly any impact on the world's major corporations or supply chains? And yet, when Wal-Mart's former CEO, Lee Scott, had his post-Hurricane Katrina Damascus experience and decided that all cotton products in Wal-Mart will be organic and all fish MSC-certified in future, then we started seeing CSR 2.0-type scalability.

Scalability not limited to the retail sector. In financial services, there have always been charitable loans for the world's poor and destitute. But when Muhammad Yunus (1999), in the aftermath of a devastating famine in Bangladesh, set up the Grameen Bank and it went from one \$74 loan in 1974 to a $\$ 2.5$ billion enterprise, spawning more than 3,000 similar microcredit institutions in 50 countries reaching over 133 million clients, that is a lesson in scalability. Or contrast Toyota's laudable but premium-priced hybrid Prius for the rich and eco-conscious with Tata's $\$ 2,500$ Nano, a cheap and eco-friendly car for the masses. The one is an incremental solution with long term potential; the other is scalable solution with immediate impact.

\section{Principle 3: Responsiveness (R)}

Business has a long track-record of responsiveness to community needs - witness generations of philanthropy and heart-warming generosity following disasters like 9/11 or the Sichuan Earthquake. But this is responsiveness on their own terms, responsiveness when giving is easy and cheque-writing does nothing to upset their commercial applecart. The severity of the global problems we face demands that companies go much further. CSR 2.0 requires uncomfortable, transformative responsiveness, which questions whether the industry or the business model itself is part of the solution or part of the problem.

When it became clear that climate change posed a serious challenge to the sustainability of the fossil fuel industry, all the major oil companies formed the Global Climate Coalition, a lobby group explicitly designed to discredit and deny the science of climate change and undermine the main international policy response, the Kyoto Protocol. In typical CSR 1.0 style, these same companies were simultaneously making hollow claims about their CSR credentials. By contrast, the Prince of Wales's Corporate Leaders Group on Climate Change has, since 2005, been lobbying for bolder UK, EU and international legislation on climate change, accepting that carbon emission reductions of between $50-85 \%$ will be needed by 2050 .

CSR 2.0 responsiveness also means greater transparency, not only through reporting mechanisms like the Global Reporting Initiative and Carbon Disclosure Project, but also by sharing critical intellectual resources. The Eco-Patent Commons, set up by WBCSD to make technology patents available, without royalty, to help reduce waste, pollution, global warming and energy demands, is one such step in the right direction. Another is the donor exchange platforms that have begun to proliferate, allowing individual and corporate donors to connect directly with beneficiaries via the web, thereby tapping 'the long tail of CSR' (Visser, 2008).

\section{Principle 4: Glocality (2)}

The term glocalization comes from the Japanese word dochakuka, which simply means global localization. Originally referring to a way of adapting farming techniques to local conditions, dochakuka evolved into a marketing strategy when Japanese businessmen adopted it in the 1980s. It 
was subsequently introduced and popularised in the West in the 1990s by Manfred Lange, Roland Robertson, Keith Hampton, Barry Wellman and Zygmunt Bauman. In a CSR context, the idea of 'think global, act local' recognises that most CSR issues manifest as dilemmas, rather than easy choices. In a complex, interconnected CSR 2.0 world, companies (and their critics) will have to become far more sophisticated in understanding local contexts and finding the appropriate local solutions they demand, without forsaking universal principles.

For example, a few years ago, BHP Billiton was vexed by their relatively poor performance on the (then) Business in the Environment (BiE) Index, run by UK charity Business in the Community. Further analysis showed that the company had been marked down for their high energy use and relative energy inefficiency. Fair enough. Or was it? Most of BHP Billiton's operations were, at that time, based in southern Africa, home to some of the world's cheapest electricity. No wonder this was not a high priority. What was a priority, however, was controlling malaria in the community, where they had made a huge positive impact. But the BiE Index didn't have any rating questions on malaria, so this was ignored. Instead, it demonstrated a typical, Western-driven, one-size-fits-all CSR 1.0 approach.

To give another example, in contrast to Carroll's (1991) CSR pyramid with its economic, legal, ethical and philanthropic layers, in a sugar farming co-operative in Guatemala, they have their own CSR pyramid - economic responsibility is still the platform, but rather than legal, ethical and philanthropic dimensions, their pyramid includes responsibility to the family (of employees), the community and policy engagement. Clearly, both Carroll's pyramid and the Guatemala pyramid are helpful in their own appropriate context. Hence, CSR 2.0 replaces 'either/or' with 'both/and' thinking. Both SA 8000 and the Chinese national labour standard have their role to play. Both premium branded and cheap generic drugs have a place in the solution to global health issues. CSR 2.0 is a search for the Chinese concept of a harmonious society, which implies a dynamic yet productive tension of opposites - a Tai Chi of CSR, balancing yin and yang.

\section{Principle 5: Circularity (0)}

The reason CSR 1.0 has failed is not through lack of good intent, nor even through lack of effort. The old CSR has failed because our global economic system is based on a fundamentally flawed design. For all the miraculous energy unleashed by Adam Smith's 'invisible hand' of the free market, our modern capitalist system is faulty at its very core. Simply put, it is conceived as an abstract system without limits. As far back as the 1960s, pioneering economist, Kenneth Boulding, called this a 'cowboy economy', where endless frontiers imply no limits on resource consumption or waste disposal. By contrast, he argued, we need to design a 'spaceship economy', where there is no 'away'; everything is engineered to constantly recycle.

In the 1990s, in The Ecology of Commerce (1994), Paul Hawken translated these ideas into three basic rules for sustainability: waste equals food; nature runs off current solar income; and nature depends on diversity. He also proposed replacing our product-sales economy with a service-lease model, famously using the example of Interface 'Evergreen' carpets that are leased and constantly replaced and recycled. William McDonough and Michael Braungart have extended this thinking in their Cradle to Cradle (2002) industrial model. Cradle to cradle is not only about closing the loop on production, but about designing for 'good', rather than the CSR 1.0 modus operandi of 'less bad'.

Hence, CSR 2.0 circularity would, according to cradle-to-cradle aspirations, create buildings that, like trees, produce more energy than they consume and purify their own waste water; or factories that produce drinking water as effluent; or products that decompose and become food and nutrients; or materials that can feed into industrial cycles as high quality raw materials for new products. Circularity needn't only apply to the environment. Business should be constantly feeding and replenishing its social and human capital, not only through education and training, but also by nourishing community and employee wellbeing. CSR 2.0 raises the importance of meaning in work and life to equal status alongside ecological integrity and financial viability. 


\section{Shifting from CSR 1.0 to CSR 2.0}

These principles are the acid test for future CSR practices. If they are applied, what kind of shifts will we see? In my view, the shifts will happen at two levels. At a meta-level, there will be a change in CSR's ontological assumptions or ways of seeing the world. At a micro-level, there will be a change in CSR's methodological practices or ways of being in the world.

The meta-level changes can be described as follows: Paternalistic relationships between companies and the community based on philanthropy will give way to more equal partnerships. Defensive, minimalist responses to social and environmental issues will be replaced by proactive strategies and investment in growing responsibility markets, such as clean technology. Reputation-conscious publicrelations approaches to CSR will no longer be credible and so companies will be judged on actual social, environmental and ethical performance, i.e. are things getting better on the ground in absolute, cumulative terms?

Although CSR specialists still have a role to play, each dimension of CSR 2.0 performance will be embedded and integrated into the core operations of companies. Standardised approaches will remain useful as guides to consensus, but CSR will find diversified expression and implementation at very local levels. CSR solutions, including responsible products and services, will go from niche 'nice-tohaves' to mass-market 'must-haves'. And the whole concept of CSR will lose its Western conceptual and operational dominance, giving way to a more culturally diverse and internationally applied concept. These shifts are summarised in the table below.

Table 5: CSR 1.0 to CSR 2.0-Meta-Level Ontological Shifts

\begin{tabular}{|l|l|}
\hline CSR 1.0 & CSR 2.0 \\
\hline Philanthropic & Collaborative \\
\hline Risk-based & Reward-based \\
\hline Image-driven & Performance-driven \\
\hline Specialised & Integrated \\
\hline Standardised & Diversified \\
\hline Marginal & Scalable \\
\hline Western & Global \\
\hline
\end{tabular}

How might these shifting principles manifest as CSR practices? Supporting these meta-level changes, the anticipated micro-level changes can be described as follows: CSR will no longer manifest as luxury products and services (as with current green and fairtrade options), but as affordable solutions for those who most need quality of life improvements. Investment in self-sustaining social enterprises will be favoured over cheque-book charity. CSR indexes, which rank the same large companies over and over (often revealing contradictions between indexes) will make way for CSR rating systems, which turn social, environmental, ethical and economic performance into corporate scores (A+, B-, etc., not dissimilar to credit ratings) and which analysts and others can usefully employ in their decision making.

Reliance on CSR departments will disappear or disperse, as performance across responsibility and sustainability dimensions are increasingly built into corporate performance appraisal and market incentive systems. Self-selecting ethical consumers will become irrelevant, as CSR 2.0 companies begin to choice-edit, i.e. cease offering implicitly 'less ethical' product ranges, thus allowing guilt-free shopping. Post-use liability for products will become obsolete, as the service-lease and take-back economy goes mainstream. Annual CSR reporting will be replaced by online, real-time CSR performance data flows. Feeding into these live communications will be Web 2.0 connected social networks that allow 'crowdsourcing', instead of periodic meetings with rather cumbersome stakeholder panels. And typical CSR 1.0 management systems standards like ISO 14001 will be less credible than new performance standards, such as those emerging in climate change that set absolute limits and thresholds. These practical shifts are summarised below. 
Table 6: CSR 1.0 to CSR 2.0 - Micro-Level Methodological Shifts

\begin{tabular}{|l|l|}
\hline CSR 1.0 & CSR 2.0 \\
\hline CSR premium & Base of the pyramid \\
\hline Charity projects & Social enterprise \\
\hline CSR indexes & CSR ratings \\
\hline CSR departments & CSR incentives \\
\hline Product liability & Choice editing \\
\hline Ethical consumerism & Service agreements \\
\hline CSR reporting cycles & CSR data streams \\
\hline Stakeholder groups & Social networks \\
\hline Process standards & Performance standards \\
\hline
\end{tabular}

\section{The DNA Model of CSR 2.0}

Pulling it all together, I believe that CSR 2.0 - or Systemic CSR (I also sometimes call it Radical CSR or Holistic CSR, so use whichever you prefer) - represents a new model of CSR. In one sense, it is not so different from other models we have seen before. We can recognise echoes of Archie Carroll's CSR Pyramid, Ed Freeman's (1984) Stakeholder Theory, Donna Wood's (1991) Corporate Social Performance, John Elkington's (1994) Triple Bottom Line, Prahalad and Hart's (2002) Bottom of the Pyramid, Porter and Kramer's (2006) Strategic CSR and the ESG approach of Socially Responsible Investment, to mention but a few. But that is really the point - it integrates what we have learned to date. It presents a holistic model of CSR.

The essence of the CSR 2.0 DNA model are the four DNA Responsibility Bases, which are like the four nitrogenous bases of biological DNA (adenine, cytosine, guanine, and thymine), sometimes abbreviated to the four-letters GCTA (which was the inspiration for the 1997 science fiction film GATTACA). In the case of CSR 2.0, the DNA Responsibility Bases are Value creation, Good governance, Societal contribution and Environmental integrity, or VEGS if you like. Each DNA Base has a primary goal and each goal has key indicators. The goals and key indicators, summarised in the table below, are what begin to show the qualitative and quantitative differences between other models of CSR and the CSR 2.0 DNA model.

Table 7: DNA Model of CSR 2.0

\begin{tabular}{|l|l|l|}
\hline DNA Code & Strategic Goals & Key Indicators \\
\hline $\begin{array}{l}\text { Value } \\
\text { creation }\end{array}$ & $\begin{array}{l}\text { Economic } \\
\text { development }\end{array}$ & $\begin{array}{l}\text { Capital investment (financial, manufacturing, social, human \& natural } \\
\text { capital) } \\
\text { Beneficial products (sustainable \& responsible goods \& services } \\
\text { Inclusive business (wealth distribution, bottom of the pyramid } \\
\text { markets) }\end{array}$ \\
\hline $\begin{array}{l}\text { Good } \\
\text { governance }\end{array}$ & $\begin{array}{l}\text { Institutional } \\
\text { effectiveness }\end{array}$ & $\begin{array}{l}\text { Leadership (strategic commitment to sustainability \& responsibility) } \\
\text { Transparency (sustainability \& responsibility reporting, government } \\
\text { payments) } \\
\text { Ethical practices (bribery \& corruption prevention, values in business) }\end{array}$ \\
\hline $\begin{array}{l}\text { Societal } \\
\text { contribution }\end{array}$ & $\begin{array}{l}\text { Stakeholder } \\
\text { orientation } \\
\text { Philanthropy (charitable donations, provision of public goods \& } \\
\text { fervices) } \\
\text { Fair labour practices (working conditions, employee rights, health \& } \\
\text { safety) } \\
\text { Supply chain integrity (SME empowerment, labour \& environmental } \\
\text { standards) }\end{array}$ \\
\hline $\begin{array}{l}\text { Environment } \\
\text { al integrity } \\
\text { restoration) } \\
\text { Renewable resources (tackling climate change, renewable energy \& } \\
\text { materials) } \\
\text { Zero waste production (cradle-to-cradle processes, waste elimination) }\end{array}$ \\
\hline
\end{tabular}


Hence, if we look at Value Creation, it is clear we are talking about more than financial profitability. The goal is economic development, which means not only contributing to the enrichment of shareholders and executives, but improving the economic context in which a company operates, including investing in infrastructure, creating jobs, providing skills development and so on. There can be any number of KPIs, but I want to highlight two that I believe are essential: beneficial products and inclusive business. Does the company's products and services really improve our quality of life, or do they cause harm or add to the low-quality junk of what Charles Handy calls the 'chindogu society'. And how are the economic benefits shared? Does wealth trickle up or down; are employees, SMEs in the supply chain and poor communities genuinely empowered?

Good Governance is another area that is not new, but in my view has failed to be properly recognised or integrated in CSR circles. The goal of institutional effectiveness is as important as more lofty social and environmental ideals. After all, if the institution fails, or is not transparent and fair, this undermines everything else that CSR is trying to accomplish. Trends in reporting, but also other forms of transparency like social media and brand- or product-linked public databases of CSR performance, will be increasingly important indicators of success, alongside embedding ethical conduct in the culture of companies. Tools like Goodguide, KPMG's Integrity Thermometer and Covalence's EthicalQuote ranking will become more prevalent.

Societal Contribution is an area that CSR is traditionally more used to addressing, with its goal of stakeholder orientation. This gives philanthropy its rightful place in CSR - as one tile in a larger mosaic - while also providing a spotlight for the importance of fair labour practices. It is simply unacceptable that there are more people in slavery today than there were before it was officially abolished in the $1800 \mathrm{~s}$, just as regular exposures of high-brand companies for the use of child-labour are despicable. This area of stakeholder engagement, community participation and supply chain integrity remains one of the most vexing and critical elements of CSR.

Finally, Environmental Integrity sets the bar way higher than minimising damage and rather aims at maintaining and improving ecosystem sustainability. The KPIs give some sense of the ambition required here $-100 \%$ renewable energy and zero waste. We cannot continue the same practices that have, according to WWF's Living Planet Index, caused us to lose a third of the biodiversity on the planet since they began monitoring 1970. Nor can we continue to gamble with prospect of dangerous and perhaps catastrophic and irreversible - climate change.

A final point to make is that CSR 2.0 - standing for corporate sustainability and responsibility - also proposes a new interpretation for these terms. Like two intertwined strands of DNA, sustainability and responsibility can be thought of as different, yet complementary elements of CSR. Hence, sustainability can be conceived as the destination - the challenges, vision, strategy and goals, i.e. what we are aiming for - while responsibility is more about the journey - our solutions, responses, management and actions, i.e. how we get there.

\section{Conclusion}

When all is said and done, CSR 2.0 comes down to one thing: clarification and reorientation of the purpose of business. It is a complete misnomer to believe that the purpose of business is to be profitable, or to serve shareholders. These are simply means to an end. Ultimately, the purpose of business is to serve society, through the provision of safe, high quality products and services that enhance our wellbeing, without eroding our ecological and community life-support systems. As David Packard, co-founder of Hewlett-Packard, wisely put it:

Why are we here? Many people assume, wrongly, that a company exists solely to make money. People get together and exist as a company so that they are able to accomplish something collectively that they could not accomplish separately - they make a contribution to society.

Making a positive contribution to society is the essence of CSR 2.0 - not just as a marginal afterthought, but as a way of doing business. This is not about bailing out the Titanic with a teaspoon which is the current effect of CSR 1.0 - but turning the whole ship around. CSR 2.0 is about designing 
and adopting an inherently sustainable and responsible business model, supported by a reformed financial and economic system that makes creating a better world the easiest, most natural and rewarding thing to do.

CSR is dead! Long live CSR!

\section{References}

Andersen, R.C., 2009. Confessions of a Radical Industrialist: Profits, People, Purpose - Doing Business by Respecting the Earth.

Carroll, A.B., 1991. The Pyramid of Corporate Social Responsibility: Toward the Moral Management of Organizational Stakeholders. Business Horizons, July-August.

Christian Aid, 2004. Behind the Mask: The Real Face of CSR. London: Christian Aid.

Cohen, B. and Greenfield, J., 1994. Ben \& Jerry's: The Inside Scoop: How Two Real Guys Built a Business with a Social Conscience and a Sense of Humor. Crown.

Drucker, P., 1993. The Practice of Management. New York: Collins.

Elkington, J. 1994. Towards the Sustainable Corporation: Win-Win-Win Strategies for Sustainable Development. California Management Review, 36(2): 90-100.

Freeman, R.E., 1984. Strategic Management: A Stakeholder Approach. Boston, MA: Pitman.

Friedman, T.L., 2008. Hot, Flat, and Crowded: Why We Need a Green Revolution - and How It Can Renew America. New York: Farrar, Straus and Giroux.

Griffin, J.J. and Mahon, J.F., 1997. The corporate social performance and corporate financial performance debate. Business \& Society, 36, p. 5.

Gupte, P., 2005. Arthur Laffer: corporate social responsibility detrimental to stockholders, The Sun New York, January 19.

Hawken, P., 1994. The Ecology of Commerce: A Declaration of Sustainability. New York: HarperBusiness.

Hollender, J. and Breen, B., 2010. The Responsibility Revolution: How the Next Generation of Businesses Will Win. Jossey-Bass.

Karnani, A., 2010. The case against corporate social responsibility. Wall Street Journal, 23 August.

Klein, N., 2000. No Logo: No Space, No Choice, No Jobs. Picador.

Klein, N., 2007. The Shock Doctrine: The Rise of Disaster Capitalism. Metropolitan Books.

Lomborg, B., 2001. Skeptical Environmentalist: Measuring the Real State of the World. Cambridge, UK: Cambridge University Press.

Margolis, J.D. and Walsh, J.P., 2001. People and Profits? The Search for a Link between a Company's Social and Financial Performance. Mahwah, N.J.: Lawrence Erlbaum Associates.

McDonough, W. and Braungart, M., 2002. Cradle to Cradle: Remaking the Way We Make Things. North Point Press.

Porter, M.E. and Kramer, M.R., 2006. Strategy and society: the link between competitive advantage and corporate social responsibility. Harvard Business Review, December.

Prahalad, C. K., \& Hart, S. L. 2002. The Fortune at the Bottom of the Pyramid. Strategy and Business, 26(54-67).

Roddick, A., 2001. Business As Unusual. London: Thorsons.

Semler, R., 1989. Managing without managers. Harvard Business Review, September.

Semler, R., 1993. Maverick: The Success Story Behind the World's Most Unusual Workplace. Century.

Stern, N., 2006. The Economics of Climate Change: The Stern Review. Cambridge, UK: Cambridge University Press.

SustainAbility and UNEP, 2001. Buried Treasure: Uncovering the Business Case for Corporate Sustainability.

SustainAbility, IRC and Ethos Institut, 2002. Developing Value: The Business Case for Sustainability in Emerging Markets.

Tapscott, D. and Williams, A.D., 2006. Wikinomics: How Mass Collaboration Changes Everything. Portfolio.

Visser, W., 2008. CSR 2.0: The New Era of Corporate Sustainability and Responsibility. CSR Inspiration Series No. 1. Published online by CSR International: www.csrinternational.org. 
Visser, W., 2008. The Long Tail of Corporate Social Responsibility. CSR Inspiration Series No. 5. Published online by CSR International: www.csrinternational.org.

Visser, W., 2010. CSR 2.0: From the Age of Greed to the Age of Responsibility. In Reframing Corporate Social Responsibility: Lessons from the Global Financial Crisis, Sun, W. et al. (eds.), Bingley: Emerald.

Visser, W., 2011. The Age of Responsibility: CSR 2.0 and the New DNA of Business. London: Wiley.

Vogel, D., 2005. The Market for Virtue: The Potential and Limits of Corporate Social Responsibility. Brookings Institution Press.

Wood, D.J. 1991, Corporate social performance revisited. Academy of Management Review, Vol. 16, pp. 691-718.

Yunus, M., 1999. Banker To The Poor: Micro-Lending and the Battle Against World Poverty. PublicAffairs. 